\title{
Kernos
}

Revue internationale et pluridisciplinaire de religion grecque antique

18 | 2005

Varia

\section{Beyond the Limits of Lyric}

The Female Poet of the Hymn to Demeter

\section{Ann Suter}

\section{Q OpenEdition \\ 1 Journals}

\section{Electronic version}

URL: http://journals.openedition.org/kernos/868

DOI: 10.4000/kernos.868

ISSN: 2034-7871

\section{Publisher}

Centre international d'étude de la religion grecque antique

\section{Printed version}

Date of publication: 1 January 2005

Number of pages: 17-41

ISSN: 0776-3824

\section{Electronic reference}

Ann Suter, « Beyond the Limits of Lyric », Kernos [Online], 18 | 2005, Online since 19 May 2011, connection on 21 April 2019. URL : http://journals.openedition.org/kernos/868 ; DOI : 10.4000/ kernos.868 


\title{
Beyond the Limits of Lyric: the Female Poet of the Homeric Hymn to Demeter*
}

\begin{abstract}
This essay investigates the possibility that the Homeric Hymn to Demeter was for entertainment composed by a woman at the Thesmophoria at Eleusis. Arguments are based on the Hymn's intensely female subject matter and subject positions, and considerations of an appropriate audience and performance context for such female concerns. These concerns are found to be identical to those of the female lyricists Sappho, Korinna, Nossis and Erinna. Composition by a woman for a female audience explains at last the uniquely humiliating treatment which Zeus receives in the Hymn. Other peculiarities find their explanations also: why there are no references to the Hymn's version of its myth until the post-Classical period, for example, or the unusual features of the Hymn's traditional diction. While perforce not conclusive, these arguments should permit us to abandon the unthinking assumption of a male author for this thoroughly female composition.

Résumé : Cet article étudie l'hypothèse selon laquelle l'Hymne bomérique à Déméter aurait été composé par une femme comme un divertissement présenté au cours des Thesmophories d'Éleusis. L'argumentation repose sur le thème fondamentalement féminin de l'Hymne, de même que sur les positions en présence, sur la question de l'audience adéquate et du contexte de la récitation pour de tels soucis féminins. Ces préoccupations s'avèrent identiques à celles des poétesses lyriques comme Sappho, Corinne, Nossis et Érinna. La composition par une femme pour un auditoire féminin explique le traitement humiliant infligé à Zeus dans l'Hymne. D'autres particularités y trouvent aussi leur explication : par exemple, les traits inhabituels de la diction de l'Hymne, ou la question de savoir pourquoi il n'existe aucune référence à cette version du mythe avant la période post-classique. En dépit de leur caractère hypothétique, ces arguments devraient nous permettre d'abandonner la prétendue évidence de l'auteur masculin d'une composition aussi féminine.
\end{abstract}

This essay explores the possibility that the Homeric Hymn to Demeter, or the poem on which it was based, was composed by a woman. Until now, most work on female authorship in the ancient world has been on lyric poets, for the excellent reason that very little in other meters by women has survived to us. But we know that women composed in other meters; we know that they composed in the epic hexameter. We know that women entered musical competitions, and we know that they composed for performance at women's festivals and for the cults of goddesses. There is, in short, no a priori reason why a woman should not have composed the HDem.

Still, no explicit evidence in the form of ancient testimony has come down to us to encourage an identification of the poet of the HDem. as a woman. To my knowledge, only Helene Foley, Louise Pratt and Eva Stehle have even

\footnotetext{
* I would like to thank Eva Stehle for her careful reading of an early draft of this essay.
} 
suggested that it may be so. ${ }^{1}$ Foley dismisses the idea immediately as too improbable, given the "public context" in which the Hymn "was likely to have been performed". Pratt is reluctant to consider it at any length; her article focusses on the treatment and depiction of old women in ancient Greece, and from that perspective, the Hymn is susceptible to different interpretations which render the evidence ambiguous. Stehle does not pursue the possibility because she feels we know too little about the performance context for the Hymn, which she takes to be the Eleusinian Mysteries.

The majority of scholars who write on the Hymn do not even consider the possibility of female authorship. This is probably so, first, because it is the heritage of our field, whose scholarship was so long confined to the male perspective, to assume the male as producer of all cultural artifacts unless there is specific and incontrovertible evidence to the contrary. Second, perhaps because the Homeric Hymns are in the epic hexameter and that is linked in our minds to "Homer", or to Phemios and Demodokos = "male". Third, the pan-Hellenic aspects of the major hymns, and the Olympian perspective they take, are thought to imply male authorship ${ }^{2}$. Last, perhaps because it is hard to believe that the rape in the Hymn, and the apparent acceptance and approval of it, was composed by a woman.

All of these hesitations are reasonable. But recent work on the known female poets of ancient Greece, and my own reading of the Hymn, offer ways around Foley's and Stehle's concerns, and counter-balancing data to add to Pratt's ambiguous evidence. The recent work isolates certain elements in female-authored poetry and identifies them as "female"; ${ }^{3}$ these elements are all in the Hymn in force. My reading argues for Persephone's agency in the narrative and suggests the presence of an all-female audience for both the core story (defined below) and the whole Hymn.

There is no question that the scenario I sketch in this essay is speculative. I lack Samuel Butler's confidence, even though recent work in psychoanalysis and literary criticism provides me with more sophisticated tools of analysis than he had at his disposal. ${ }^{4}$ It is one thing, however, to extrapolate character-

\footnotetext{
1 Stehle (1997), p. 211-212; Pratt (2000), p. 55-59; FOley (1994), p. xi-xii. Pratt points out that the HDem. was attributed to Homer in antiquity, which suggests "the ancients did not consider it a female creation" (56). Note, however, that the ancients also attributed the HHermes to Homer, and modern scholarship has not hesitated to challenge that. See D. BECK (2001), p. 56 n. 12 for references to Janko and Hoekstra.

2 STEHLE (1997), ch. 4, esp. p. 177-196 on the Hymn to Apollo. SNYDER (1989) also associates the local with female and pan-Hellenic with male. GeNTILI (1988), p. 116 does not see this correlation. There is certainly no gender-linked specialization in subject matter. Perhaps Stehle is referring only to bardic poetry. But see my arguments below for the female bard's identification with Persephone in the HDem.

3 See, for example, Skinner (in RABinowitz, Richlin eds, 1993); STIGERS [STEHLE] (in FOLEY ed., 1981); DEJEAN (1987); RAYOR (1993). Contrast these arguments with those in WEST (1977), where he argues that Erinna was really a man. I am grateful to Lucia Nixon for bringing this article to my attention. See ARTHUR [KATZ] (1980) for a rebuttal to West.

${ }^{4}$ See DOUGHeR (2001) for a fine discussion of the pros and cons of Butler's theory that the Odyssey was written by a woman.
} 
istics from texts known to be by women and identify them as "female" in contrast to attitudes evident in works by men in the same genre. It is another to use those characteristics to diagnose the gender of the author of an anonymous text. We are all familiar with the possibilities of "ventriloquism" and "rhetorical postures", and so this essay will surely raise the question "How reliable are these characteristics for identifying the biological sex of an anonymous author?" Still, I believe it is a useful exercize to see how powerful a speculative argument can be made. We have all too long assumed a male poet for the Hymn, despite much contradictory evidence.

This essay first reviews the historical context for the possibility of a female poet for the HDem. Then I turn to the Hymn and summarize arguments in my book showing that the Hymn is a reworking of traditional materials and identifying a core story where Persephone and Demeter are the agents of the narrative. I note the Hymn's many similarities to the characteristics of female lyric. Then I consider what kind of audience and performance context would be appropriate for such a poem. The essay concludes with an assessment of the Hymn which reverses the usual assumptions; I assume that a woman composed it for a female audience. This assumption solves some critical and historical problems, and gives a fresh view on what has come to be known as an ancient text that "somehow enter[s] into the female consciousness better than other Greek texts do".

Eva Stehle has made a forceful case for the impossibility of female bards.? Perhaps she is right, if by "bard" we mean only the kind in Homer, that is, a singer of songs for mixed, or all-male, audiences at the court of a king. But this is not the full picture, even when we include the poetic competitions we hear about in Hesiod ( $W E D, 651-659$ ). It is surely possible to compose bardic poetry - narrative hexameter poems dealing with mythical or heroic subjects for performance contexts other than those which would require social events such as men's games or men's feasting, or for the poetic competitions. Sappho did the former. Korinna did the latter, although it is unclear if she entered

\footnotetext{
5 PRATT (2000), n. 21 for a discussion of the "question of whether a distinct female voice can occur in poetry created by men"; DOUGHER (2001), p. 173 for "rhetorical postures"; RABINOWITZ (2001), p. 193 for "style one could choose to employ"; STEHLE (1997), p. 322; SKINNER (in RABINOWITZ, RichLIN eds, 1993) for a classic example of ventriloquism (Diotima in Plato's Symposium).

${ }_{7}^{6}$ SUTER (2002), esp. chs. 1-3.

It was with amusement and some chagrin that, after I had drafted this essay, I read the page proofs for the book (SUTER 2002) on which it is based. Despite my (obvious) intellectual understanding of the arguments I made in the book, in it I clearly maintained the conventional assumption of a male poet. The contrast in attitude of this essay and the attitude in the book is instructive.

8 PRATT (2000), p. 55.

9 STEhle (1997), ch. 4.
} 
dactylic hexameter poetry in competitions. ${ }^{10}$ Helen also is portrayed doing the former in Odyssey IV. ${ }^{11}$

It also seems likely that there were different types of bardic poetry. Gentili distinguishes the type of performance Demodokos gives at Od. VIII, 258-369, which he calls "epic-lyric" and argues has a strophic structure since it was accompanied by dancing, from "purely recitational performances in the normalized hexameter" familiar to us from the Homeric and Hesiodic poems. ${ }^{12}$ Other examples of epic-lyric texts could be some of Sappho's narrative poems with mythical subjects -44 on the wedding of Hektor and Andromache, 44A on Artemis' acquisition of everlasting virginity, or the one-line frag. 42 on Leto and Niobe - and other of her dactylic verse not in hexameters. These would be examples of what Page calls "typically Lesbian verse", performance context is disputed, at least their existence, and their female authorship, are not. It is clear as well from Sappho and Korinna's poetry that they were thoroughly familiar with epic diction.

Our information is more plentiful for later times: there were Anyte ("the female Homer, ${ }^{15}$ ), Erinna, Moero and Hedyla writing in epic hexameters. ${ }^{16}$ Women also, we know, wrote hymns to deities, intended for performance at festivals and as part of religious cult worship. ${ }^{17}$ They also composed choral songs to be sung by choruses of girls and for the "population at large", whose subject matter was both local and pan-Hellenic myth.

Anthropological data offer myriad comparanda. ${ }^{19}$ In many traditional societies it is common for women as well as men to be poets and storytellers, although usually not the chief ones. Storytelling, public verbal activity, impromptu poetic performances were not carried on only in formalized, occasional, or elite contexts, but as daily activity in many situations and for a

${ }^{10}$ Sappho, 104-106 (Loeb Classical Library), eg., are in dactylic hexameter; 107-109 probably are. Korinna victorious in competition with Pindar: Pausanias, IX, 22, 2; Aelian, Varia Historia XIII, 25. Several of the fragments of Korinna's surviving poetry seem to be in dactyls, some are definitely in dactylic hexameter (e.g., PAGE ed., Poetae Melici Graeci, 1975, p. 657-658, 669, 674).

1 Goldhill (1991), p. 61-66 sees Helen as a bard, as Odysseus has long been seen in his stories to the Phaiakians. Never mind that her story may be discredited (DOHERTY [1995], p. 130135); she, like Odysseus and in the same peformance context, sings the story of Troy.

12 Gentili (1988), p. 14-15. See also p. 125 for other early composers of this "citharoedic" poetry.

13 PAGE (Sappho and Alcaeus, 1975), p. 65-66.

14 See, for example, WinkLer (in Foley ed., 1981) on Sappho 16 (Homer), or RAYOR (1993) on Korinna 655 (Hesiod) (PAGE ed., PMG, 1975). See also Plutarch, Moralia $496 \mathrm{D}$ on female Homerids.

15 Antipater of Thessaloniki, Anth. Pal. IX, 26, quoted in SNYDER (1989) as an epigraph.

16 See RAYOR (1991), p. 11, and passim for translations and commentary. POMEROY (1977) discusses women professionals of all kinds in the 6th-1st centuries B.C.E.; see esp. p. 4-57

for poets. See also DEMARTINO (1991).

17 SNYDER (1989), p. 16-18 (Sappho); 50-51 (Korinna); 54 (Praxilla); 60 (Telesilla).

18 SNYDER (1989), p. 40-45; STEHLE (1997), ch. 2.

19 Eg., Turner (1980), p. 143-144; GOSSEN (in BAUMAN ed., 1977); SHERZER (in Bauman ed., 1977); BECKWITH (1919); ZAYKO (1995); HERZFELD (1985). 
variety of audiences. The same materials could be performed in different ways, and depending on the immediate audience, they could be epic, hymnic, blaming, praising, all in the daily competition of self-presentation. It is not easy to believe that the women of archaic Greece did not participate in these activities, as their peers did in other societies and times.

This is the necessary circumstantial evidence. It shows that it was technically possible for a woman to have composed poetry such as the HDem. If the Hymn was composed by a woman, all the separate elements outlined above would have had to come together: familiarity with mythological themes, skill with dactylic verse, a working knowledge of traditional diction, ${ }^{20}$ an interested audience, and an appropriate performance occasion. The first three we have already seen combined in several ancient women poets. It is the last two elements which constitute the chief challenge to the possibility of female authorship for the Hymn. To determine an appropriate and likely audience and performance occasion, it is necessary first to examine the poem; its subject matter and atmosphere, attitudes and perspective will help to suggest where, under what circumstances, and for whom the Hymn would command attention and respect.

Much valuable feminist work has been done in the last 20 years on the HDem., but it has all remained within the framework of a patriarchal reading of the poem. By that I mean a framework that takes Hades to be the active agent in Persephone's abduction and Zeus to be behind it all. This scholarship has pointed out the patriarchal model of marriage in the presumed exchange of women between Zeus and Hades. Others have seen Hades' abduction of Persephone as a brutal rape and have challenged earlier scholars' apparent assumption that such acts were normal and do not require comment. All these have seen Persephone as a victim, the helpless pawn of the patriarchy, and Demeter, at best, as fighting a rear-guard action against male control. My, slightly different, feminist perspective sees Persephone as an active participant in the events of the Hymn. This, in making Hades a reactor to Persephone's initiative, automatically makes him less of a rapist and more peripheral. ${ }^{21}$

I believe that it is Persephone who sets the narrative in motion when she reaches out to pick the narcissus, and that she does not have sexual relations

${ }^{20}$ How they came by this knowledge is not known - any more than it is known how male bards in Archaic Greece acquired their skills. One must imagine it was something like the way in which they acquired the knowledge and skills of lamentation: exposure from childhood to public performances, and the practise and development of skill in (probably) the female environments of home, work and festival. See F. Beck (1975), STEARs (in Blundell, Williamson eds, 1998), p. 123, and L. O'Higgins (2003), esp. chs. 2 and 4.

The only scholar to attribute some agency to Persephone to my knowledge is PERKINS (1996), p. 140, although she identifies a different act (the "lie" to Demeter at 406-413) as the evidence of it. 
with Hades until she accepts the pomegranate seed. ${ }^{22}$ Furthermore, she does not accept the seed until he has agreed that she return to her mother. It is true that it is Zeus' will ( $\beta$ ou $\lambda \tilde{\eta} \sigma l, 9)$ that all this happens. We are told of his plan in the very first lines, and it is rounded off near the end of the poem when Demeter and Persephone go to Olympos to "dwell beside Zeus" (483488). These passages frame the story proper; I call them the "Olympian frame", a manifestation of the trend of Olympianization found in all the major Hymns. ${ }^{23}$ Within the Olympian frame is the story of Persephone's coming of age and Demeter's reaction to her maturation. This is the core story, which was "Olympianized" in the Hymn's version of the myth ca 600 B.C.E. ${ }^{24}$ My initial arguments in this essay are for the possibility of female authorship of the core story only. I make a separate argument considering data which may indicate a female author for the whole Hymn.

The notion of a distinction between the core story and the Olympian frame is critical to my argument for female authorship. The distinction indicates that the Hymn we have is a reinterpretation of the myth, and of the power relationships among the deities whose activities it records. The first and last few lines of the Hymn set the core story into a frame where Zeus' will and hegemony are asserted over the core story's events. ${ }^{25}$ But perhaps the most definitive element of the reinterpretation is Persephone's speech to her mother (406-433), which retells the story of the myth, which the narrator has just told us. There are differences in emphasis, even apparent contradictions, between Persephone's and the narrator's versions, but the chief difference is that Persephone's has an internal audience. The poet of the Hymn repeats the story so as to present Demeter as a model of how the poem's audience should react to the new version of the myth being offered in the Hymn. The poet is at the same time speaking in Persephone's voice to Demeter and sua voce to the ancient audience. ${ }^{26}$ Demeter accepts Persephone's new status as an adult and Queen of the Underworld; the poet's audience, likewise, is asked to accept the new, Zeus-dominant, power relationships in this new version of the myth. This argument is supported by certain elements in the

\footnotetext{
22 In the latter point I follow others; see SUTER (2002), p. 57-58 for eating the pomegranate seed as symbolic of sexual intercourse.

${ }^{23}$ First discussed by CLAY (1989)

${ }^{24}$ I use Clay's term because hers was the original argument for it. For the purposes of this essay, however, "pan-Hellenization" - the term most often used in analyses of women's poetry should be understood as indicating the same trend, which began, like "Olympianization", in the Archaic age.

${ }^{25}$ It is not possible to give specific line numbers for the frame; the poet managed the transition from frame to core story and back again very skillfully. For instance, at the beginning, the frame probably ends at 14 , but the action in 15 (Persephone reaching for the narcissus, her first action as a subject which starts the core story) has obviously been introduced by the poet in 4-7. Still, the idea of the narcissus as a $\delta$ ónov, and Gaia's complicity, are part of the frame.

${ }^{26}$ This is the argument for the metanarrative function of Persephone's speech if we assume male authorship of the whole Hymn. The slightly different interpretation below, which assumes female authorship, would make the address to the audience a part of the parody of the archaic male poet's strategy. See below, p. 31-32.
} 
diction of the speech ( $\left.\nu \eta \mu \varepsilon \varrho \tau \dot{\varepsilon} \alpha \pi \dot{\alpha} \nu \tau \alpha-406 ; \dot{\alpha} \lambda \eta \theta \varepsilon^{\prime} \alpha \pi \alpha^{\prime} \nu \tau \alpha-433\right)$, which are a feature of the Olympianization of the Hymn. Other indications that a reworking of traditional materials is taking place can be seen in the use and

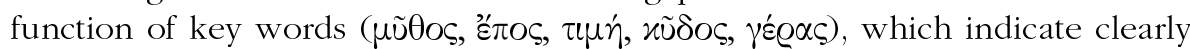
that Demeter and Persephone are the authoritative figures in the narrative, not Zeus, as asserted in the Olympian frame, and that in the core story his will is muddled and ineffective. ${ }^{27}$ It is clear, for example, that Zeus knows nothing about the existence or effect of pomegranate seeds; this is a device known in the Hymn only to Demeter and Hades and perhaps Persephone. ${ }^{28}$

Once the Olympian frame is recognized for what it is - an effort to impose Zeus' patriarchal control on a story for and about females - it is clear that the action of the story begins when Persephone reaches out to pick the narcissus. It is time for her to grow up; she is ready; she reaches out on an impulse of her own nature. She subsequently controls the situation to the extent that she does not accept Hades as a lover - that is, eat the pomegranate seed (371374) - until her return to Demeter is assured, and until Hades promises to be a good $\alpha$ xoí $\eta \subseteq$ for her, giving her supreme honours among the souls in the Underworld (360-369), and even lending Hermes his chariot to take her back to her mother in style. Demeter's agency in the story is in need of arguing also, perhaps: it has not always been acknowledged that she refuses to accept Zeus' proferred honours, and that she brings him to heel with her power over the vegetation of the earth. He capitulates, and sends Hermes to fetch Persephone back - forever, so he thinks. It is only Hades' idea of the pomegranate seed, and Persephone's cooperation in it, that ensure that even part of Zeus' plan in the Olympian frame will be accomplished.

The core story of the Hymn recounts Persephone's coming of age ${ }^{29}$ and Demeter's accommodation to her daughter's new status. It is a story where women are dominant, are the active agents, and are the ones who undergo change and growth. The male, Hades in this case, is the "marker of position" in a female story. ${ }^{30}$ Persephone is ready for sexual maturity; she reaches for

\footnotetext{
27 For the use of $\mu \tilde{u} \theta 0 c$ and हैंTOs, see MARTIN (1989). For the implications in traditional diction of $\nu \eta \mu \varepsilon Q \tau \varepsilon \dot{\varepsilon} \alpha$ and $\alpha \lambda \eta \theta \varepsilon \dot{\varepsilon} \alpha$, see NAGY (Homeric Questions, 1996). For discussions of these words, as well as $\tau \iota \mu \dot{\eta}, \chi \tilde{\delta} \delta 0 \varsigma$, and $\gamma \dot{e} \varrho \alpha \varsigma$, see SUTER (2002), ch. 2.

${ }^{28}$ SUTER (2002), ch. 2. Note also that, although the Olympian frame asserts Zeus' command of the events of the story, this was never so in the two major cults Demeter/Persephone cults at Eleusis, the Thesmophoria and the Mysteries. Both of these have an aitiology in the Hymn, but in neither the aitiologies nor the cults did Zeus have any part.

29 I distinguish here between Persephone's psychological coming of age, which is part of the story, and the story as an initiation rite in the anthropological sense, which is not. See SuTER (2002), p. 13-14 and ch. 4. CALAME (1997), p. 124-125 also argues, using different evidence, against the Hymn having the tri-partite pattern of an initiation rite.

30 HIRSCH (1989), p. 2. She quotes the phrase from DE LAURETIS (1984), p. 109. Hirsch's analysis of the plot of the HDem. is a good example of how persistent the patriarchal reading of the Hymn can be, even among feminist critics. Despite her perception of the plot as a coming of age story, and her model of woman's writing as a "palimpsest" overlaid by men's (21), she does not see Persephone's agency in the narrative: “... the story of mother and daughter depends on Hades, the male figure whose intervention constitutes the disruption which prompts the
} 
the narcissus; Hades responds. She accepts the male, and mature sexuality, but does not wish to give up her relationship to her mother. ${ }^{31}$ The mother, after her own struggle - the search, the episode in Eleusis with Demophoön, the battle of wills with Zeus ${ }^{32}$ - accepts her daughter as a mature woman. What was first a relationship of power (the mother) and weakness (the daughter when a child) becomes one of equals. It is obvious that Persephone has grown up, but so has Demeter, who takes the last step in her own maturation when she accepts her daughter's maturity. In this story, the specifics of how Persephone acquires her sexual maturity are secondary. The abduction was sudden and frightening ${ }^{33}$ certainly, even though she was ready, but the situation was not altogether out of her control, as we saw above. Indeed, it is the Olympian frame, which claims the abduction was planned by Zeus and Hades, which makes Hades' response to Persephone's readiness seem like a rape. Demeter, for her part, relinquishes her position of power; at the end of the poem, the mother and daughter are equals. This is the development of the relationship of the two chief characters in the Hymn, as I read it.

It is curious, despite the clear sequence of events in the Hymn, that scholars have read it exactly as the Olympian frame sets out, accepting that what happens in the story is what Zeus willed, and ignoring the fact that this necessarily includes his own humiliation by Demeter. This fact, however, will perhaps give us a clue later to the gender of the poet.

Recent scholarly work on poetry known to be by women isolates numerous characteristics as being typical, if not actually diagnostic, of femaleauthored poetry. These characteristics include subject matter, themes, perspectives, stylistic preferences. They were developed by careful analysis of the texts available to us, using feminist theoretical vocabulary, and comparing the treatment of similar subjects by male poets. According to these criteria, the HDem. - at least the core story - should have been composed by a woman.

narrative." (5; see also 5-6, 29 and 35-36). More recently there is WILLIAMSON (1995), p. 111 and 125: "She herself [Persephone] plays a passive part", "Persephone... is the object of rape by a male deity, rather than a sexual subject"; Ormand (1999), p. 32: "We do not actually see Persephone as a subject in this poem".

31 ChOdorow (1978); SuTER (2002), ch. 3. See also HeIlbrun (1990), p. 70-71: perhaps Woolf's "search for the mother" has a literary forebear after all.

32 Demeter has her own plan ( reaction to Persephone's coming of age in SUTER (2002), ch. 3.

33 In this, as in many of the details of the story, the emotional and psychological accuracy of the young girl's story is remarkable. Distasteful as the metaphor of rape is, it is perhaps not an inept description - as metaphor; "abduction" is probably a more accurate word. "He swept me off my feet" we might say. Persephone's (clinically typical) ambivalence about growing up, which helps to explain certain parts of the text (why the narcissus is an athurma (toy, 16), her cry to Kronides at 21, her "unwillingness" at 30, 344, etc.), are examined in detail in SUTER (2002), ch. 3. 
Perhaps the most important way in which the Hymn's core story resembles women's poetry is in how it treats the myth it retells. Rayor points out, in her discussion of Korinna 654 (PMG), where Rheia gives birth to Zeus and then saves him from the predations of Kronos, how "Korinna consciously repossesses myth" ${ }^{34}$. She argues that Korinna's treatment of Rheia refashions the male treatment of the story in Hesiod's Theogony, giving Rheia the central role and timê. Winkler ${ }^{35}$ analyses Sappho 16 in a similar fashion, pointing out how she retells the story of Helen going to Troy with Helen as the powerful determiner of her own action. The earliest references we have to Demeter and Persephone as mother and daughter, and to Persephone's abduction by Hades with Zeus' knowledge, are also in the Theogony (912-914). It is unclear whether the core story is repossessing the myth from its male Hesiodic version, or whether Hesiod was putting a male slant on an originally female myth. The important point is that we have different, and gender-related, treatments in the two poems.

Several writers have offered lists of the subject matter typical of women's poetry in the ancient Greek world. Snyder includes parents and children, children's play, daily living, household affairs, woolworking, pets, spiritual and ritualistic matters, love relationships, friendships, "emotional attachment and commitment between women". She finds women's activities are described, rather than women's physical characteristics, and although women poets may sometimes use military metaphors, their poems never describe battle scenes. ${ }^{36}$ Elsewhere, Snyder notes Sappho's concern with "the inner emotions of love and desire and the role of memory in assuaging the pain of separation". ${ }^{37}$ In the same way, the poet of the Hymn's core story describes the thoughts and feelings of the females in the narrative - distress, grief, anger, fear, longing, suspicion, joy - but never the feelings of the male characters. ${ }^{38}$ Memory too is important in the story; Persephone remembers her mother and misses her in the Underworld (343); her emotion is left at that. For Demeter, however, it functions as an urgent stimulus to her efforts to retrieve Persephone. Unlike the women in Sappho's poems, she is a goddess and does not have to accept the separation from a loved one that a male tries to impose on her.

Skinner summarizes the subjects of Sappho and Erinna's poetry in this way: "the sphere of women's religious and domestic lives and...their deep emotional attachments to other women". She also discusses Nossis: "Nossis addresses the problem of how female selfhood is achieved and manifested" in poem 7 (Anth. Pal. IX, 604); in poem 8 (Anth. Pal. VI, 353), Nossis shows "the biological and psychological complexities of the mother-daughter

34 RAYOR (1993), p. 223; discussion of Korinna on p. 223-225.

35 WinkLER (in FOLEY ed., 1981), p. 71-73. See also DUBOIs (1996).

36 SNYDER (1989), p. 21, 97-98 and 153.

37 SNYDER (in POMEROY ed., 1991), p. 17.

38 A possible exception might be when Hades $\mu \varepsilon i \delta \eta\rceil \varepsilon v . . .0 ̈ \varphi \varrho v \sigma \iota \nu$ (357-8 "smiled with his eyebrows"). 
relationship", and "hints at the struggle over the daughter's autonomy latent in the mother-daughter dyad". Her poems reflect the "transcendent importance of women's experience - of intimate bonding, especially the bonding of mother and daughter". ${ }^{39}$

This subject matter is precisely what we see in the core story of the Hymn. With the exceptions of woolworking and pets, every one of the items mentioned by Snyder is present as foreground or background in either the Demeter/Persephone story, or in the episode in Eleusis when Demeter is welcomed by Metaneira and her daughters as nurse for Demophoön. Persephone "achieves female selfhood", and "manifests" it to her mother in her assured recitation of her adventures (406-433). The "struggle over the daughter's autonomy" constitutes the bulk of the Hymn's narrative. It motivates Demeter's grief at Persephone's disappearance, and her determination to get her back. Persephone struggles against her mother, and also within herself. She is ambivalent about whether she wants to grow up: she reaches for the narcissus, but then shrieks for her father when the outcome of that gesture occurs in Hades' arrival. She is swallowed up in mother earth (= regression to childhood with Demeter?) but later accepts the pomegranate seed as her introduction to adult sexuality. The struggle over her autonomy culminates in the reunion scene: the goddesses run to embrace one another, but immediately Demeter is suspicious and questions Persephone about eating, knowing what may have happened. In Persephone's reply we have a skillful performance, designed both to assert her new status as an adult ("Yes, I ate the seed" 411-412), and to placate her mother and remain close to her ("but he forced me to" 413). We know this is not true; at least there was no mention of force in the narrator's recounting of the incident (371-4). Whatever Demeter may be thinking, she accepts the story, and "All day long... they warmed each other's hearts and minds" (434-435).

Another critical similarity of the core story to the work of female lyric poets is the subject position taken by Persephone and Demeter. Here the poet makes use of the hymnic convention which introduces the divinity to whom the hymn is dedicated in the accusative case, and after a few lines switches to the nominative. Persephone is kept in the accusative case until 15, far longer than most, and her first action as subject is the more noteworthy for the unusual delay. Demeter too is introduced in the accusative in line 1, but does not appear in the nominative until 39 when she reacts to Persephone's cry. She is thereafter in a subject position also, doing her share of making things happen. Noone denies her the right to her anger, ${ }^{41}$ which manifests itself in the drought and famine on earth and threatens life itself, and the honours of the gods. The behaviour of Zeus and the other gods on Olympos in the core story is always in reaction to her actions. Her value system (the motherdaughter bond) prevails over theirs (the supremacy of the father).

\footnotetext{
39 SkINNER (in POMEROY ed., 1991), p. 20 (Sappho and Erinna), 28 and 37 (Nossis).

40 The translations in this essay are from ATHANASSAKIs (1976).

41 HiRsch (1989), p. 36 sees this too.
} 
Persephone and Demeter become one another's objects. Demeter sees her initially as an object - her daughter, in a subordinate position vis-à-vis her own power as mother. ${ }^{42}$ She never doubts that Persephone wants to return to her as much as she wants her back. Nor does Demeter doubt her own right to interrogate Persephone when she returns. But then we see that this power relationship has been challenged after all, by Persephone herself when she ate the pomegranate seed; she and her mother must renegotiate their relationship. They do: no longer hierarchical, it is now balanced, noncompetitive. Their reunion establishes Persephone as her own subject in Demeter's eyes; Demeter, of course, has always been a subject in her daughter's. The Greek of the passage reflects this mutual recognition

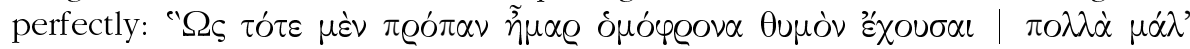

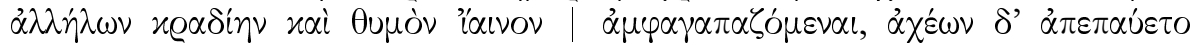

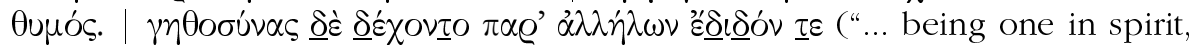
| they warmed each others hearts and minds in many ways | with loving embraces, and an end to sorrow came for their hearts/ as they took joys from each other and gave in return" - 434-437). The very sound pattern of the d's and t's in 437 underscores the mutual love of mother and daughter, and the balanced equality of their individual, new selves: " $\mathrm{d}-\mathrm{d}-\mathrm{t}$ (with one another) $\mathrm{d}-\mathrm{d}-\mathrm{t}$ ". This phrase is unique in traditional hexameter diction. ${ }^{43}$

This is an excellent example of the mutuality, the interconnectedness, the intertwined receiving and giving which is so often cited as characteristic of the narrator's perspective and stance towards her addressee in Sappho's poetry. Demeter and Persephone are "positioned as both subject and object of desire. ${ }^{.44}$ In the same way, de Beauvoir comments on lesbian love: "[T]here is no struggle, no victory, no defeat; in exact reciprocity each is at once subject and object, sovereign and slave; duality becomes mutuality." ${ }^{45}$ To be sure, the "desire" in the Hymn is not erotic. But psychologists remark on the narcissistic impulse in mothers and daughters who see and love themselves in each other. ${ }^{46}$ This impulse, as it appears in the core story, is aptly described by the words of Williamson and de Beauvoir.

One of the aspects of male-authored poetry intended to be performed by women, which Stehle points out in Alkman's Partheneia, is the male

\footnotetext{
42 Skinner aptly describes this relationship as "encapsulating prepatriarchal political relations" (personal communication).

43 RICHARDSON (1974), p. 43-52 ("Language Peculiar to the Hymn to Demeter") does not mention it, however, in the introduction to his commentary. He calls 437 a "doubtful" "weak" line "which could have been added to fill a [possible] lacuna" (p. 66 and ad loc.). He does not say why it is doubtful or why there may be a lacuna. Let us permit the perfection of the line in its context to assuage our doubts and restore its strength.

44 Williamson (1995), p. 148 uses this phrase to describe the relation of the women in Sappho's audiences to one another.

45 Quoted in STIGers [STEHLE] (in Foley ed., 1981), p. 54.

46 CHODOROW (1976), p. 102, 195 and 202
} 
definition of the female and the female acceptance of his definition. ${ }^{47}$ Such poetry was performed in a public context, before a mixed-sex audience. The Hymn has often been seen as just such an effort of the male (through the voice of a male poet) to define the respective roles of father, mother, daughter and daughter's intended husband, and to present them as a model for human society. ${ }^{48}$ Such definition is largely irrelevant to Demeter and Persephone, however; their subject positions are validated by the core story. What gets defined in this poem is not the female and her proper role in a patriarchal society, but the adult mother/daughter relationship. ${ }^{49}$

Comparing the characteristics of female-authored poetry and those of male-authored poems in the same genre with similar subject matter has been a persuasive method of isolating characteristics of female lyric. ${ }^{50}$ The HDem. has instructive comparanda also, especially in how the other Homeric Hymns praise the deities to whom they are addressed. In the other Hymns Zeus' will is supreme; in none are the glory and honour of the addressee achieved apart from it, and Aphrodite is even humiliated in her hymn, so as to accommodate Zeus' pique at having been subjected to her powers. The exact opposite is true in the HDem.; Persephone and Demeter acquire their honours independently of Zeus and it is Zeus who is humiliated. This suggests a very different perspective and sensibility in its poet, a perspective and sensibility that are female and reflect understanding of how things happen and look in a woman's world. An ethic of hierarchy underlies the other Hymns, in contrast to that of cooperation and sharing in the HDem., where hierarchy is challenged and condemned by Demeter in her reaction to Zeus' efforts, and changed to equality in her relationship with Persephone. An ethic of sharing is apparent also in the division of Persephone's time between Hades and Demeter. They come to an arrangement which both Demeter and Hades accept, and which Persephone implicitly desires since it is her coming of age story and it was she who reached for the narcissus and set the narrative in motion. Zeus was not involved in this arrangement; his instructions to Hermes were simply to bring Persephone back (337-338), with no mention of any time-sharing with Hades.

\footnotetext{
47 STehle (1997), ch. 2. See also Calame (1977), I, p. 4: "La fonction du chœur lyrique", esp. p. $2,1-3$ and 5 .

Cf. NAGY (Poetry as Performance, 1996), p. 57: "II]n Alcman's Partheneion, I propose that...primary archetypal figures named Hagesikhora and Agido, are models being acted out by real chorus-members in performances held on a seasonally-recurring basis."

See ZAJKO (1995), p. 33 for how point of view can determine the "collective significance of any given story". See also LARSON (1995), p. 100: "In the logic of myth, patriarchal marriage and strong mother-daughter bonds are incompatible."

See n. 3 above.
} 
Such are the characteristics of the Hymn which argue for the possibility of female authorship. It is now possible to turn to the question of audience and performance occasion. Who would make a likely audience for a poem like the core story? What kind of audience - by their presence, their interest, their approving reception - would give the singer of this song the authority to sing it? It is difficult to believe that an all-male group could have been the intended audience for the story of such intensely and specifically female experiences as those which Persephone and Demeter undergo. Even a mixed group of worshippers seems less likely for the core story than an all-female one, although possible for the whole Hymn, with its Olympianizing parts.

The appropriate audience for such a story as this, I suggest, may be found in groups of young women gathered to celebrate their coming of age. Not at the mixed-sex ceremonies for which Alkman wrote his Partheneia, which focussed on the readiness for marriage of young women in the social context of the polis ${ }^{52}$, but at the all-female occasions concerned with the actual steps of a young woman's physical and emotional growth, acceptance of mature sexuality, and the new relationship with the mother. We have records of such rites for different areas of Greece, especially Athens and Sparta, but none of these was sacred to Demeter or Persephone. We have none for Eleusis, ${ }^{53}$ although it is scarcely credible that young Eleusinian women did not manage their transition to adulthood without some form of ritual. However, we have in the HDem. an aitiology for the Thesmophoria (the Demophoön episode), and we do know that the Thesmophoria was celebrated at Eleusis, probably at least from the early Archaic age. ${ }^{54}$ Its general purpose was fertility: it included digging pits where pigs were deposited and from which the rotted remains were retrieved by women known as "Bailers" for spreading on fields. If, as is probable, it was celebrated in a fashion similar to the one in Athens, it was for women only, and concerned not only the fertility of the earth, but that of the human female as well. It is unlikely that the performance of the core story was part of the actual rites. At least, the cult acts of the Athenian Thesmophoria had little to do with the story of Persephone's abduction and return, although they were later, in the 5th century, interpreted as being

\footnotetext{
51 RAYOR (1993), p. 223 identifies "two key aspects of "women-identified' writing": the repossession of male myth (discussed above for the core story) and addressing a female audience.

52 Cf. STEHLE (1997), p. 318, on Sappho's poems: "only among women could women perform as self-defining subjects". This complements her argument that women in performance before mixed audiences are defined by the male poet. $C f$. n. 47 above.

53 Although it is not necessary to this argument, I believe that the core story was probably composed for an audience in Eleusis, as was the Hymn almost certainly. See SuTER (2002), ch. 9. For a summary of the coming of age rites, see SUTER (2002), ch. 3, based chiefly on CALAME (1977), p. 67-68 and 443 and SOURVINOU-INWOOD (1991), p. 75-77.

800-700 B.C.E., perhaps. See ClinTON (in HäGG et al. eds, 1988), p. 72-76 and (1993), p. $113-115$
} 
modelled in part on the myth. ${ }^{55}$ It is likelier that the story was performed simply as entertainment. Indeed, it may have been the performance of the poem at the festival that started or encouraged the later identification of the festival with the Hymn's story.

This festival provides an appropriate occasion for the story, as its concerns and participants included young brides and their sexual maturation and fertility. It may have been, in some cases, the first time a daughter and mother were together again after the daughter's wedding removed her from her natal home. The performance of this poem would have reflected and resonated with their reunion. Skinner, citing Winkler, suggests such activities: "At separate cult gatherings such as the Adonia and the Thesmophoria, to say nothing of daily private interaction in their own homes, these women had abundant opportunities to speak and joke among themselves, to chant and dance, to adapt a flexible mythic heritage to their purposes - in short, to propagate their own discourses in relative isolation. ${ }^{56}$ Stehle suggests something similar, that the story of Demeter and Iasion may have been told at the Thesmophoria as a version of the "goddess mates with a human male" myth, in which the female is the dominant character. ${ }^{57}$ Note also her description of "community" poetry: "The notion of community performance as providing reflection and model means that community performers speak both for and to the audience and community at large." Such poetry can "mark a turning point or critical moment in the life of the community. ${ }^{, 58}$ Just so for a performance of the core story at the Thesmophoria; only the "community" is that of the Thesmophoriazusae only, not the whole polis.

The Eleusinian Thesmophoria, then, seems a good occasion for performing the core story. What about one for the whole Hymn, with its efforts to introduce Zeus as the eminence behind it all, and the aition for the Eleusinian Mysteries at the end? A mixed-sex audience is possible here, at the Mysteries themselves, perhaps, or in the musical competitions of the Eleusinia, a harvest festival sacred to (among other deities) Demeter and Persephone and celebrated at Eleusis at least as early as the 6th century. ${ }^{59}$ The implication of

55 See SuTER (2002), ch. 9. Note that the Thesmophoria was celebrated all over the Greek world; local cults could not all have been based on the HDem., although it is possible that some form of coming of age story or, likelier, a story of the disappearance and return of a goddess of the earth's fertility, was involved. For a possible course of the combination of two of the story types in the Hymn at Eleusis - the abduction and the origin of the rulers of the Underworld -, see CLINTON (1992), p. 60-62.

56 SKINNER (in DEMARTINO ed., 1991), p. 188-189; WINKLER (1990), p. 188-209. See also ZAJKO (1995), and above, n. 20 for the probable context of girls' education in poetic skills.

57 STEHLE (in GREENE ed., 1996), p. 209-210.

58 STEHLE (1997), p. 28.

59 CLINTON (1979), p. 2-3; probably from the 7th century, if the remains of the Athens Eleusinion are any guide. See MiLes (1998), p. 8, 15 and 19 and my discussion, SuTER (2002), p. 196-197. There were similar competitions at the Eleuhunia near Sparta, "a sort of Spartan equivalent of the Thesmophoria" (PARKER [in HÄGG et al. ed., 1988], p. 103). "Eleuhunia" is the Spartan vocalization of "Eleusinia". He also mentions an Eleusinia with musical and athletic 
the Hymn as a reworking of traditional materials is that there were males in the audience, for they would presumably be the ones most pleased with the new, male-dominant power relations, and the ones who would most approve of Zeus arranging his daughter's marriage. The story was reenacted during the celebration of the Mysteries, although probably only parts of it. ${ }^{60}$ This does not mean that the Hymn itself was performed as part of the rite, however. It is likelier that it would simply have been entertainment at the Mysteries in the same way the core story may have been at the Thesmophoria. At the Eleusinia the whole Hymn could have been either entertainment or competition. On either occasion (Eleusinia or Mysteries), it would have been a story about the goddesses to whom both cults were sacred, in the same locale as they were celebrated, and, in the case of the Mysteries, recounting how the festival originated.

The problems with these scenarios are numerous, however. A woman performing her own work before such audiences, while not impossible ${ }^{61}$, is surely rare. Was then the whole Hymn composed and performed by a male after all? This is a familiar strategy: the male recasts the female-authored poem from his own perspective and with his own agenda. There are difficulties in the Mysteries or the Eleusinia as occasions for a male performance of the Hymn, however. As we have seen, Zeus does not get what he sets out after, but is instead bested by Demeter. ${ }^{62}$ It is implausible that an audience with males would have responded well to this, irrespective of who was performing it and despite the poem's pan-Hellenizing aspects. Further, Zeus had no part in the celebration of the Mysteries or the Eleusinia, so an effort to make him the cause of the abduction story has little point from the perspective of these cults.

There remains (for this essay) one possible arrangement of these elements - poet/audience/performance context - and it does account for these difficulties. Perhaps the whole Hymn - not just the core story - was composed by a woman and performed at the Thesmophoria. This would produce a new interpretation of the confrontation between Zeus and Demeter. In such a reading, the Olympian frame becomes a mocking parody of and commentary on the dominant male poetic strategy emerging during the Archaic age, that is, the Olympianization, or pan-Hellenization, of materials under the mythic (but not cultic, it should be remembered) hegemony of Zeus on Olympos, a strategy which asserted for the male the sole authority for speaking on mythical matters. ${ }^{63}$ Thus, the underlying plan of the HDem., with

\footnotetext{
competitions at Athens (101-102). These festivals were apparently for both men and women, as the only competition winner we know of was Damonon for chariot races.

60 See MYlonas (1961), p. 247-285, esp. 261-73; CLINTON (1992), p. 84-90

61 We hear of Korinna a century or so later entering contests where she competed with men. See SNYDER (1989), p. 41-43 for the stories of her victory over Pindar.

62 This is Stehle's concern too with the Mysteries as the Hymn's performance context. See STEHLE (1997), p. 212, n. 143.

${ }^{63}$ See STEHLE (1997), ch. 4.
} 
its Olympian frame surrounding earlier mythic materials and asserting the power of Zeus, is the same as that of the other long Hymns. In this parody of the plan, however, Zeus is outmanoeuvred by Demeter and his power is mocked. He humiliates Aphrodite in the HAphr. (this is consistent with the assumption of a male poet for it), but in the HDem., he himself is (consistent with the notion of a female parody).

Parallels to such mockery are close at hand: the Hymn to Hermes can be read as a parody of the epic style, eg., in its treatment of the heroic cattle raid. We see such mockery of male heroics also in Sappho 16, where she undercuts the male glorification of military razzle-dazzle with her assertion of

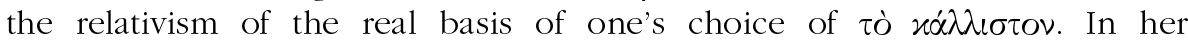
epithalamia also we have similar, more light-hearted fun made of the bridegroom's physique in the parodic reuse of the heroic epithet "the equal of

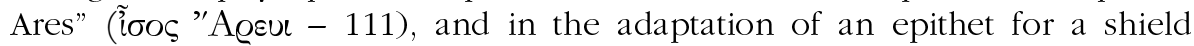
when she indirectly describes the doorkeeper's huge feet by mentioning his

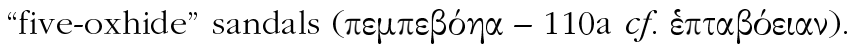

O'Higgins describes "the Thesmophoria's darker side" and suggests that "women's cultic speech may have included a more subversive agenda". She adduces the behaviour of the women of Aristophanes' Thesmophoriazusae as an example of something that "reflect[s] a genuine function of the women's festival that did not conform to 'official' [= male] ideology" ${ }^{64}$ In the Hymn we have just such derisive treatment of Zeus: his will is thwarted; he is shown to be ignorant (of the function of the pomegranate seed); he is out-manoeuvred by Demeter and Hades and Persephone. In the context of a female poet's mockery of the pompous, empty majesty of Zeus, the god's standard epithets take on amusing and provocative meanings. At the end of the Hymn, when he sends Rheia to offer (again unsuccessfully) honours to Demeter and to proclaim (redundantly; $c f$. 393-400) the division of Persephone's time between Hades and Demeter, he is described as "far-seeing, loud-thundering Zeus" (441). He has just been bamboozled; hasn't seen anything until too late; has been pontificating pointlessly from Olympos. But he is still the "lord of the dark clouds" (468) which presumably are responsible for his being so fogged in. ${ }^{65}$ In any case, Demeter ignores his offer. The female principle is triumphant. A few lines later, after Demeter has instructed the men of Eleusis in the establishment of the Mysteries, she and Persephone go to Olympos "for the company of the other gods. There they dwell beside Zeus" who is (still) delighting in his thunder (484-485). ${ }^{66}$ The poet then praises the goddesses,

64 D. O'Higgins (in LARDinOIS, MCCluRE eds, 2001), p. 155-156.

${ }^{65}$ The possibility of this take on his epithets first occurred to me while working on a libretto for the opera "Potnia" based on the Hymn, set by a colleague in the Music Department. In those liberating circumstances, I was suddenly myself a female poet working on the myth in the HDem., able to use the standard epithets as I chose.

See SUTER (2002), p. 37-38 and ch. 7 for how unusual this is. Nowhere else in Archaic poetry are Demeter and Persephone found on Olympos, and Demeter is found with other Olympians only rarely in 6th and early 5th century Attic vase painting. 
invokes them once more, and asks for their gifts in return for her song. This ending is an excellent example of what Skinner describes in Sappho: "In none of these texts does Sappho close her eyes to the ontological reality of the masculine order. She recognizes it, as a prior and controlling presence, but still avows the ethical superiority of her nonnormative subject position, her radically woman-centered approach to existence.", For "Sappho" read "the female poet of the HDem." The women of the Thesmophoria accept the maleinclusive and male-run Mysteries.

Still, an aition for the Mysteries towards the end of the Hymn perhaps sits oddly in a poem performed at the Thesmophoria. How to understand this? There are several ways. First, as just mentioned, it conforms to the pattern found in Sappho's verses. Second, is the presence of this aition any more surprising in a hymn performed at the all-female Thesmophoria than the outmanoeuvering of Zeus and marginalization of Hades by a powerful goddess, and the focus on such intensely female issues as female coming of age and the mother-daughter relationship would be on a performance occasion where men are present? In my opinion, much less so. Once again, we have perhaps been too accustomed to assume male authorship and not question the evidence that contradicts it, seeing problems only when we assume female authorship. We do not have to disprove male authorship; after all, the Hymn has come down to us as an anonymous composition.

Third, the Mysteries, for which there is the aition at the end, is part of the worship of Demeter and Persephone at Eleusis, and as such should not surprise us in a hymn dedicated to them. It is, in all probability, ${ }^{68}$ an outgrowth, a "universalization", of the Thesmophoria, and in the early stages of its development at the time of the composition of the Hymn. One of the main agendas of the Hymn is the commemoration of the joining together of Demeter and Persephone in worship in the Thesmophoria, where Persephone alone had been worshipped in earler times, and in that of the Mysteries, which were developing with Demeter as its chief goddess. This forms a plausible reason, I suggest, for the inclusion of this aition. ${ }^{69}$

67 SKINNER (in GREENE ed., 1996), p. 187. The scenes of human women's lives which we see depicted in the Demophöon episode at Eleusis are also evidence of this recognition. For example, Metaneira tells her husband Demeter's demands, but it is the husband who orders and oversees the construction of the temple. Metaneira may hire and fire palace help in the women's quarters, but she does not give orders to men for public activities.

68 CLINTON (1992), p. 29-35 and 60-62; and SuTER (2002), p. 196-197. See also CAlAME (1997), p. 132-133 for another, promising approach to the same subject.

69 Note that in the Hymn's aitia, it is Demeter alone who founds both cults $(270-274,292-$ 300, 473-483). If we had only the Hymn to inform us, we would never suspect that Persephone was worshipped also in these cults. The Hymn is emphasizing the power of the new goddess, at the expense of the old one whose cult she is taking over. This is argued in detail in SUTER (2002), chs. $6,8,9$, with a summary p. 14-20. 
Much of what has just been laid out qualifies as fulfillment of my promise (p. 19, above) to assume a female poet, and reassess the Hymn from that perspective. Certainly the most pervasive change, if we take this attitude to the Hymn, is the easy recognition of the same female characteristics in it that have been pointed out in the women lyricists. The Hymn takes its place alongside the poetry of Sappho, Korinna, Nossis, and the others, producing its own examples of female attitudes, interests, and subject positions. It no longer excites our wonder that the Hymn "somehow enter[s] into the female consciousness better than other Greek texts do", or that it "put[s] the experience of ancient women and its symbolic importance into some perspective". ${ }^{70}$ If we assume female authorship, the parodic character of Zeus' clumsy efforts to run things becomes clear, and we have an explanation at last for the unique treatment he receives. ${ }^{71}$ We stop overfocussing on Hades and Zeus and can see what the bulk of the poem is about.

This assumption answers other interesting questions also, both textual and non-textual. For example, the poet takes over the voice of Persephone when she tells Demeter her version of what has happened to her. Shelmerdine and Stehle speak of the identification of the poet with the divinity to whom a hymn is dedicated. ${ }^{72}$ In these cases, the divinities (Hermes and Apollo, respectively) are male, so noone has ever questioned the identification, although Stehle makes a point of the male persona of the poet of the HAp., and of his emphatic self-presentation as a male. Her example of the poet's use of Apollo's voice is at HAp. 363-374: "the bard speaks as Apollo speaking to the snake, but he also directs his words... straight to the audience." ${ }^{73}$ This is exactly what we have seen with Persephone's tale to Demeter - the poet speaking not only in the voice of the character Persephone, but in her own at the same time, to her own audience. The poet here derives her authority in the same way the poets of the HHerm. and the HAp. derive theirs, by identifying herself with the poem's authoritative figure. Persephone delivers the longest ( $=$ the most authoritative ${ }^{74}$ ) speech-act in the Hymn, and it is the Hymn's own story. But let us return for a moment to the customary assumption, that of a male poet for the Hymn. Could he not identify himself not only with Persephone ("ventriloquism"), but with the Zeus of the Olympian frame as well, acquiring male authority thereby over the whole Hymn, as the poet of the HAp. does with his similar self-identification? This assumption leads to a

${ }_{71}$ PRATT (2000), p. 55; FOLEY (1994), p. xi.

71 The narrative examples of this uniqueness need no rehearsing. For its reflections in the poem's diction and usage (especially of the words muthos and epos), see SuTER (2002), ch. 2, based on MARTIN (1989)

72 Shelmerdine (1984), p. 207; STEHLE (1997), p. 178-196, esp. 192-193. The HDem. is always called just that, but both the invocation at the beginning and the one at the end call upon both Demeter and Persephone. See SuTER (2002), ch. 6.

73 STEHLE (1997), p. 193. The quotation continues shortly thereafter: "He becomes 'male' by derogating the 'female'.'

74 See discussion in SUTER (2002), p. 27-32. with references to MARTIN (1989). Persephone's speech is one of those designated a muthos, that is, an "authoritative speech-act", in the Hymn. 
problem, though, which should by now be familiar: Zeus' omnipotence and omniscience, asserted in the Olympian frame, turn out to be severely limited and badly flawed in this Hymn. Why should a male poet wish to create and identify with such a figure? In the end, it really makes better sense for the poet to be a woman mocking the "normal" male assumption of authority. She is responding to, and in part deriving her authority from, an all-female audience.

Another anomaly in the HDem. concerns its place within the oral hexameter tradition. Its diction and several of its stylistic devices exhibit characteristics which are not paralleled in the Homeric poems, some not even in the other Hymns. I have just noted how the unique treatment suffered by Zeus in the narrative is reflected in the usage of the words muthos and epos. In no other work of Archaic hexameter poetry are Zeus' muthoi or epea rejected or ignored, as they are in the Hymn by Demeter, who substitutes her own muthoi, which prove stronger than Zeus'. Richardson notes as well, that "[m]any words and forms are found in the Hymn which do not occur in Homer, Hesiod, or other early epic (Hymns, Cycle, inscriptions, etc.)." ${ }^{75} \mathrm{He}$ lists peculiarities in diction, formulae, forms, usage, and the treatment of the digamma. Could this wide-ranging difference from its companions in Archaic hexameter indicate that the Hymn is part of a separate female tradition, another strain of the oral tradition? Skinner suggests the possibility of such a female poetic inheritance in the lyric tradition, and O'Higgins one for iambic poetry. ${ }^{76}$ There perhaps existed such in the hexameter tradition also, if the HDem. is any guide.

There are other aspects of the Hymn, both narrative and stylistic, which differentiate it from Homer. Demeter and Persephone as a mother/daughter pair, for instance, have no place in Homer, where there is no connection between the two. Persephone is the awesome Underworld goddess, Demeter a rather minor grain divinity, little more than a personification of "bread" except as part of Zeus' list of dalliances in the $\Delta$ iò $\varsigma \dot{\alpha} \pi \alpha \tau \dot{\eta}$ (Iliad XIV, 326). It is not until Hesiod's Theogony (912-914) that the two goddesses have a mother-daughter relationship, and the bare outline of the abduction is related. In the scenario of a female oral tradition, the story would have been based on the kernel in Hesiod and "repossessed" by women.

D. Beck examines the Hymn's use of direct and indirect discourse and its use of speech-framing formulae. She finds these usages unique in the hexameter tradition. Furthermore, they "highlight the emotions and narrative

75 RICHARDSON (1974), p. 43.

76 Skinner (in Greene ed., 1996), p. 189; O'Higgins (in LARDinOIS, MCClure eds, 2001), p. 143. This possibility for the Hymn is taken up also, briefly, by PratT (2000), p. 56. POMEROY (1977), p. 56 sees "no indication at all that there was a 'feminist school' of poetry". She was writing, however, before the scholarship of the 1980s and 1990s cited in this essay.

See Clay (in MORRIs, POWEll eds, 1997), p. 492 and passim, for bibliography on separate schools of epic development for Homer and Hesiod and the Hymns. This scholarship does not take into account the possibility that the separateness is due to gender. 
importance of the mother-child relationship between Demeter and Persephone. ${ }^{, 78}$ This, according to what we have seen above, is a typical concern in female-authored poetry.

Lucia Nixon has investigated another aspect of the Hymn, which points to particularly female concerns and knowledge: the uses of two plants which play important roles in the Hymn's story, pennyroyal and the pomegranate seed. These plants were known and used in the ancient world as abortifacients and birth control devices. ${ }^{79}$ She suggests that Hades, in giving the pomegranate seed to Persephone may be unknowingly and foolishly ensuring that he will never be a father. This may well be a legitimate way to interpret the significance of the pomegranate seed $;^{80}$ if so, it would provide yet another joke on the ignorant male for the women in the poem's audience, who know how to manage their own bodies' fertility in ways men do not even suspect. ${ }^{81}$

One last puzzle, an historical one this time, may find a solution in the concept of the Hymn as a woman's poem composed by and performed for women. It has long been noted, but never explained, that there are no clear and unambiguous references to the Hymn in literature until the post-Classical period, "no direct mention of the Homeric Hymn and scarcely anything which can reasonably be identified even as a reminiscence or echo of it" in classical literature. $^{82}$ Likewise, the myth of Persephone's abduction and Demeter's wanderings in search of her seems unknown to Attic vase painters until the second half of the 5th century, and even then, references seem to be to a version different from the Hymn's. ${ }^{83}$ If the Hymn, and the core story upon which it is based, were the work of women, and performed only at allwomen's festivals, it is quite understandable that it would not be readily available to the eyes and ears of a male public and included in their artistic productions, especially given its depiction of Zeus. I mentioned above (p. 2930) that the cult acts of the Thesmophoria seem originally to have had little to do with the story of the Hymn. I suggested also that performances of the Hymn at such festivals might have been the impetus for the eventual identification of Persephone's story with the celebration. This speculation may now be carried farther: it may be in the very process of that identification,

78 D. BECK (2001), p. 73.

79 NIXON (in HAWLEY, LEVICK eds, 1995), p. 85-88

80 NIXON (in HAwley, LEVICK eds, 1995), p. 92; see also SUTER (2002), p. 57-58 and n. 29 for the standard interpretations of eating the seed: as sexual intercourse, and as binding the eater to return to the one who provided the thing eaten.

81 Nixon also remarks on references by Aristophanes, Peace, 706-712; Lysistrata, 87-89, which "suggest that plant lore and preparation were familiar subjects to ordinary women as well as to the male authors who wrote about them" (88). These references may be the earliest evidence we have for male knowledge of such lore; the medical writings of Hippocrates (the earliest source Nixon cites) do not begin until the 4th century, two hundred years after the composition of the Hymn

82 WALTON (1952), p. 105.

83 CARPENTER (1992); SUTER (2002), p. 212-213. 
which seems to have begun in the late 5th century, that the channel was found for the emergence of the Hymn into the world of men.

If we assume a female poet or poets, then, we have the following. Zeus' ignominious treatment is given a likely explanation. ${ }^{84}$ The remarkable acuity of the Hymn's perception of female experience, and the gender-linked manner of its expression, become the simple reflection of the nature and socialization of its poet. The assumption of Persephone's voice by the poet to tell the authoritative muthos of the Hymn now no longer requires an extraordinary ventriloquism; here, women really are talking about themselves. ${ }^{85}$ The differences in the Hymn's diction and usage from other branches of oral tradition have a single explanation; they explicitly support some of the female author arguments, and do not contradict any. And we have a plausible reason for the complete lack of recognition of the Hymn in other extant Archaic and Classical works of literature and in Attic vase painting until the late 5th century. We have found as well a congenial performance occasion for both the core story and, if we accept that ancient women were capable of parody while still recognizing their ultimate place in the "ontological reality of the male order" ${ }^{86}$, of the whole Hymn as well, at the Thesmophoria.

Is this enough to prove female authorship of the Hymn? I do not think so, although I believe it offers a strong enough challenge to the assumption of male authorship that that assumption should be abandoned. And there are other ways to assess the possibility, which are beyond the scope of this essay. I have privileged feminist scholarship in the present analysis, and barely touched on scholarship where gender issues are not the focus of concern. The present arguments, for example, should be brought into relationship with work on the oral tradition. The concept of multiformity ${ }^{87}$ provides an excellent context for a female tradition and for interplay between male and female treatments of the same materials. The "unHomeric" nature of the Hymn's diction and word-order should be investigated further ${ }^{88}$. Training of bards in the Archaic age, whether male or female, is a subject on which very little work has been done. Perhaps others will pursue these possibilities. For the

${ }^{84}$ In comedy, satyr plays, and iambos, of course, the gods are mocked by male poets. The Hymn, however, has never (to my knowledge) been argued to belong to either of those genres. There is also the more general mockery of the heroic style in the HHerm. (cf. p. 32 above). It should be noted, however, that the fact that the Hymn is a parody of the hymn genre and its new Olympianizing techniques in no way means that the women who composed and sang it were not sincere devotees of Persephone and Demeter.

${ }^{85}$ Cf. STEHLE (1997), p. 322: "Men's speech in performance is only about men."

86 See n. 67 above.

87 See Finkelberg (2001) and in reply, NAGY (2001), based on NAGY (1990, Poetry, 1996).

88 RICHARDSON (1974), p. 287 ad 413 
present, let us return to one incontrovertible fact: the Homeric Hymn to Demeter has not come down to us as the work of a man. We do not have to disprove that. It has come down to us as an anonymous creation. From the perspective of that starting point, on which all scholars agree, I think it is not at all impossible that it is the work of women. Indeed, it is even likely.

Ann SUTER

e-mail: asu9043u@postoffice.uri.edu

\section{Bibliography}

ARTHUR [KATZ], M.B., "The Tortoise and the Mirror: Erinna PSI 1090", CW 74 (1980), p. 53-65. ATHANASSAKIS, A.N., The Homeric Hymns: Translation, Introduction, and Notes, Baltimore, 1976. BARnARD, S., "Anyte: Poet of Children and Animals", in DE MARTino (ed.), Rose di Pieria, p. 63176

Bauman, R. (ed.), Verbal Art as Performance. Rowley, Mass., 1977.

BECK, D., "Direct and Indirect Speech in the Homeric Hymn to Demeter", TAPhA 131 (2001), p. $53-74$.

BECK, F.A.G., Album of Greek Education: the Greeks at School and at Play, Sydney, 1975.

BEckwITH, M.W., "The Hawaiian Romance of Laieikawai", in Thirty-third Annual Report of the Bureau of American Ethnology, 1911-12, Washington, D.C., 1919.

Blundell, S., M. Williamson (eds.), The Sacred and the Feminine in Ancient Greece, London / New York, 1998.

Bowman, L., "Nossis, Sappho and Hellenistic Poetry", Ramus 27 (1998), p. 39-59.

BurnetT, A.P., 1979. "Desire and Memory (Sappho Frag. 94)", CPh 74 (1979), p. 16-27.

-, Three Archaic Poets: Archilochus, Alcaeus, Sappho, Cambridge (Mass.), 1983

BuxTOn, R., Imaginary Greece: The contexts of mythology, Cambridge (Eng.), 1994.

CALAME, C., Les chours de jeunes filles en Grèce archaïque, Rome, 1977.

—, "Sappho's Group: An Initiation into Womanhood", in E. GREENE (1996), p. 113-124.

_-, “L'Hymne homérique à Déméter' comme offrande”, Kernos 10 (1997), p. 111-133.

CARPENTER, T., "On Demeter and Perspehone in Archaic Art from Attica", Paper presented at the annual meeting of the American Philological Association, New Orleans, 1992.

CARTER, J.B., S.P. MORRIS (eds.), The Ages of Homer: A Tribute to Emily Townsend Vermeule, Austin, 1995.

CHODOROw, N., The Reproduction of Mothering: Psychoanalysis and the Sociology of Gender, Berkeley, 1978 .

ClaY, J.S., The Politics of Olympus: Form and Meaning in the Major Homeric Hymns, Princeton, 1989.

—, "The Homeric Hymns", in I. MORRIs, B. POwell (1997), p. 489-507.

Cunton, K., "The $I G^{2}$ 5, the Eleusinia, and the Eleusinians", AJPh 100 (1979), p. 1-12.

-, "Sacrifice at the Eleusinian Mysteries", in R. HÄGG (1988), p. 69-80.

-, Myth and Cult: The Iconography of the Eleusinian Mysteries, Stockholm, 1992.

-, "The Sanctuary of Demeter and Kore at Eleusis", in N. MARINATOS, R. HÄGG (1993), p. 110-124.

Coluins, D., "Improvisation in Rhapsodic Performance", Helios 28.1 (2001), p. 11-27.

DEJEAN, J., "Fictions of Sappho", Critical Inquiry 13.4 (1987), p. 787-805.

De Martino, F. (ed.), Rose di Pieria, Bari, 1991.

_-, "Appunti sulla scrittura al femminile nel mondo antico", in F. DE MARTINO (1991).

DE LAuretis, T., "The Female Body and Heterosexual Presumptions", Semiotica 67 (1987), p. 12979. 
DUBOIS, P., "Sappho and Helen", in E. GREENE (1996), p. 79-88.

DOHERTY, L., Siren Songs: Gender, Audiences, and Narrators in the "Odyssey", Ann Arbor, 1995.

Dougher, S., "An Epic for the Ladies: Contextualizing Samuel Butler's Theory of Odyssey Authorship", Arethusa 34.2 (2001), p. 173-184.

FinkelberG, M., "The Cypria, the Iliad, and the Problem of Multiformity in Oral and Written Tradition", CPh 95 (2000), p. 1-11.

Foley, H. (ed.), Reflections of Women in Antiquity, New York et al., 1981.

- (ed.), The Homeric "Hymn to Demeter", Princeton, 1994.

Gentili, B., Poetry and its Public in Ancient Greece: From Homer to the Fifth Century (tr. and introd. A.T. COLE), Baltimore / London, 1988.

Goldhill, S., The Poet's Voice: Essays on Poetics and Greek Literature, Cambridge (Eng.), 1991.

Goody, J. (ed.), Literacy in Traditional Societies, Cambridge (Eng.), 1968.

- , "Introduction", in J. GOODY (1968).

GOODY, J., I. WATT, "The Consequences of Literacy”, in J. GOODY (1968).

Gossen, G.H., "Chamula Genres of Verbal Behavior", in R. BAUMAN (1977).

GrEENE, E., "Apostrophe and Women's Erotics in the Poetry of Sappho", TAPhA 124 (1994), p. 4156.

- (ed.), Reading Sappho: Contemporary Approaches, Berkeley, 1996.

_-, "Sappho, Foucault, and Women's Erotics", Arethusa 29.1 (1996), p. 1-14.

Gubar, S., “The Blank Page' and the Issues of Female Creativity” in E. SHOwalter (1985), p. $292-$ 313.

HäGG, R. et al. (eds.), Early Greek Cult Practice. Proceedings of the 5th Symposium at the Swedish Institute at Athens, 26-29 June, 1986, Stockholm, 1988

-, "Sappho and Her Social Context: Sense and Sensibility" in E. GREENE (1996), p. 125-142.

HAwleY, R., B. LEVIck (eds.), Women in Antiquity: new assessments, London / New York, 1995.

HeILBRun, C.G., Hamlet's Mother and other women, New York, 1990.

—, "Virginia Woolf and James Joyce", in C.G. HeIlbrun (1990), p. 58-77.

Henderson, J., "Older Women in Attic Old Comedy", TAPhA 117 (1987), p. 105-129.

HERZFELD, M., The Poetics of Manhood: Contest and Identity in a Cretan Mountain Village Princeton, 1985.

HiRsch, M., The Mother-Daughter Plot: Narrative, Psychoanalysis, Feminism, Bloomington / Indianapolis, 1989

Kolodny, A., "A Map for Rereading: Or, Gender and the Interpretation of Literary Texts", New Literary History 11 (1980), p. 451-67.

LARDinOIS, A., "Subject and Circumstance in Sappho's Poetry", TAPhA 124 (1994), p. 57-84.

-, "Keening Sappho: Female Speech Genres in Sappho's Poetry", in A. LARDinoIs, L. McClurF (2001), p. 75-92.

LARDiNOIS, A., L. MCCluRE (eds.), Making Silence Speak: Women's Voices in Greek Literature and Society, Princeton, 2001.

LARSON, J., Greek Heroine Cults, Madison, 1995

Loeb Classical Library, Greek Lyric I, (tr. D.A. CAMPBELL), Cambridge (Mass.) and London, 1982.

LYONS, D., Gender and Immortality: Heroines in Ancient Greek Myth and Cult, Princeton, 1997.

MarinAtos, N., R. HÄGG (eds.), Greek Sanctuaries: New Approaches, London and New York, 1993.

MARTIN, R., The Language of Heroes: Speech and Performance in the "Iliad", Ithaca, 1989.

MCCluRE, L., Spoken Like a Woman: Speech and Gender in Athenian Drama, Princeton, 1999.

Miles, M.M., The Athenian Agora: Results of excavations conducted by the American School of Classical Studies at Athens, vol. XXXI: The City Eleusinion, Princeton, 1998.

Mitchell, W.J.T. (ed.), On Narrative, Chicago / London, 1980

Morris, I., B. Powell (EDS.), A New Companion to Homer, Leiden, New York and Köln, 1997.

Mylonas, G., Eleusis and the Eleusinian Mysteries, Princeton, 1961.

NAGY, G., Pindar's Homer: the Lyric Possession of an Epic Past, rev. ed., Baltimore, 1990. 
-, Homeric Questions, Austin, 1996.

-, Poetry as Performance, Cambridge (Eng.), 1996.

-, "Homeric Poetry and Problems of Multiformity: The Panathenaic Bottleneck", CPh 96 (2001), p. 109-119.

NiXON, L., "The Cults of Demeter and Kore", in R. HAwlEY, B. LEVICK (1995), p. 75-96.

O'Higgins, D.M., "Women's Cultic Joking and Mockery", in A. LardinOIS, M. McClure (2001), p. $37-160$.

-, Women and Humor in Classical Greece, Cambridge (Eng.), 2003.

O'Higgins, L. see O'Higgins, D.M.

ONG, W.J., Orality and Literacy: The Technologizing of the Word, London / New York, 1982.

ORMAND, K., Exchange and the Maiden: Marriage in Sophoclean Tragedy, Austin, 1999.

Page, D. (ed.), Poetae Melici Graeci, Oxford, 1975.

- (ed.), Sappho and Alcaeus, Oxford, 1975.

PALlONE, M.R., "L'epica agonale in età ellenistica", Orpheus 5 (1984), p. 156-166.

PARKER, H.N., "Sappho Schoolmistess", TAPhA 123 (1993), p. 309-351.

PARKER, R., "Demeter, Dionysus and the Spartan Pantheon", in HäGG et al. (1988), p. 99-104.

Perkins, C.A., "Persephone's Lie in the Homeric Hymn to Demeter", Helios 23.2 (1996), p. 135142.

Plutarch, Moralia, Loeb Classical Library, vol. VI, Cambridge (Mass.), 2000.

POMEROY, S.B., "TECHNIKAI KAI MOUSIKAI: the Education of Women in the Fourth Century and in the Hellenistic Period", AJAH 2 (1977), p. 51-68.

- (ed.), Women's History and Ancient History, Chapel Hill / London, 1991.

Powell, B.B., "Text, Orality, Literacy, Dictation, Education, and Other Paradigms of Explication in Greek Literary Studies", Oral Tradition 15.1 (2000), p. 96-125.

PraTT, L. 2000, "The Old Women of Ancient Greece and the Homeric Hymn to Demeter", TAPhA 130 (2000), p. 41-66

Rabinowitz, N.S., "Personal Voice/Feminist Voice", Arethusa, 134.2 (2001).

Rabinowitz, N.S., A. Richlin (eds.), Feminist Theory and the Classics, New York / London, 1993.

RAYOR, D. J., Sappho's Lyre, Berkeley, 1991.

_, "Korinna: Gender and the Narrative Tradition", Arethusa 26:2 (1993), p. 19-231.

Richardson, N.J. (ed.), The Homeric Hymn to Demeter, Oxford, 1974.

SHELMERDINE, C., "Hermes and the Tortoise", GRBS 25.3 (1984), p. 201-8.

SHERZER, J.F., "Cuna Ikala: Literature in San Blas", in R. BAUMAN (1977).

SHOwalter, E. (ed.), The New Feminist Criticism: Essays on Women, Literature, and Theory, New York, 1985.

SkINNER, M.B., "Corinna of Tanagra and Her Audience", Tulsa Studies in Woman's Literature 2.1 (1983), p. 9-20.

_, "Rescuing Creusa: Introduction", Helios 13.2 n.s. (1986), p. 1-24.

-, "Greek Women and the Metronymic: A Note on an Epigram by Nossis", Ancient History Bulletin 19 (1987), p. 39-42.

-, "Sapphic Nossis", Arethusa 22 (1989), p. 5-18.

-, "Nossis Thêlyglôssos: The Private Text and the Public Book", in S.B. Pomeroy (1991), p. 2147.

-, "Aphrodite Garlanded: Erôs and Poetic Creativity in Sappho and Nossis", in F. DE MARTINO (1991), p. 77-96.

-, "Woman and Language in Archaic Greece, or, Why is Sappho a Woman?", in N.S. RABINOWITZ, A. Richlin (eds.), Feminist Theory and the Classics [= "Women and Language", in E. GreENE (1996)], p. 175-192.

SNYDER, J.MCI., The Woman and the Lyre: Women Writers in Classical Greece and Rome, Carbondale / Edwardsville, 1989 
-, "Public Occasion and Private Passion in the Lyrics of Sappho of Lesbos", in S.B. Pomeroy (1991), p. 1-19.

SOuRvinou-InwOOD, C., 'Reading' Greek Culture: Texts and Images, Rituals and Myths, Oxford, 1991.

StEARS, K., "Death Becomes Her: Gender and Athenian Death Ritual", in S. Blundell, M. Williamson (1998), p. 113-127.

STEHLE [STIGers], E., "Sappho's Private World", in H. Foley (1981), p. 45-61.

-, "Romantic Sensuality, Poetic Sense: A Response to Hallett on Sappho", in E. GreENE (1996), p. $143-149$

-, Performance and Gender in Ancient Greece: Nondramatic Poetry in its Setting, Princeton, 1997.

SuTER, A., The Narcissus and the Pomegranate: an Archaeology of the Homeric "Hymn to Demeter", Ann Arbor, 2002.

Thomas, R., Oral Tradition and Written Record in Classical Athens, Cambridge (Eng.), 1989.

Turner, V., "Social Dramas and Stories about Them" in W.J.T. Mitchell (1980).

Walton, F.R., "Athens, Eleusis, and the Homeric Hymn to Demeter", HThR 45 (1952), p. 105-114.

WEST, M.L., "Erinna”, ZPE 25 (1977), p. 95-119.

Williamson, M., Sappho's Immortal Daughters, Cambridge (Mass.), 1995.

-, "Sappho and the other woman", in E. GREEN, (1996), p. 248-264.

WinkLER, J.J., "Gardens of Nymphs: Public and private in Sappho's lyrics", in H. FOLEY (1991), p. 3-89 [= "Double Consciousness in Sappho's Lyrics", in J.J. WINKLER (1990), p. 162-187].

-, The Constraints of Desire: The Anthropology of Sex and Gender in Ancient Greece, New York / London, 1990.

- "The Laughter of the Oppressed: Demeter and the Gardens of Adonis", in J.J. WinkLER (1990), p. 188-209.

ZAJKO, V., "Speaking Myth", Arethusa 28.1 (1995), p. 21-38. 